\title{
Protective Effect of Nelumbo nucifera Plant on Dextran Sodium Sulfate-Induced Ulcerative Colitis in Rats
}

\author{
Jignesh I. Patel ${ }^{1}$ Monika Kumbhani ${ }^{1}$ Morvi M. Raval ${ }^{1}$ \\ ${ }^{1}$ Department of Pharmacology, B. K. Mody Government Pharmacy \\ College, Rajkot, Gujarat, India \\ Address for correspondence Jignesh I. Patel, MPharm, PhD, B. K. \\ Mody Government Pharmacy College, Polytechnic Campus, Near Aji \\ Dam, Rajkot 360003, Gujarat, India \\ Ann Natl Acad Med Sci (India) 2022;58:78-86. \\ (e-mail: jigneshmpharma@yahoo.com).
}

\begin{abstract}
Keywords

- ulcerative colitis

- DSS

- Nelumbo nucifera
\end{abstract}

Objectives Ulcerative colitis is a global disease with increasing incidence and worldwide prevalence. So this study was undertaken to observe antiulcerative colitis activity of ethanolic extract of seeds of Nelumbo nucifera plant on dextran sodium sulfate (DSS)-induced ulcerative colitis in rats.

Materials and Methods The effect of ethanolic extract of $N$. nucifera seed (EENNS) was studied on DSS-induced ulcerative colitis in albino Wistar rats for 11 days. Disease pathogenesis was assessed by evaluation of disease activity index (DAI) including the following parameters: change in body weight, stool constituency, rectal bleeding in animals. Estimation of myeloperoxide (MPO), nitric oxide (NO), and antioxidant parameters like malondialdehyde (MDA), superoxide dismutase (SOD), and catalase level was performed in colon homogenate of animals. TNF- $\alpha$ (tumor necrosis factor- $\alpha$ ) level was measured in colon homogenate using rat TNF- $\alpha$ ELISA kit.

Statistical Analysis Significant differences (mean \pm standard error of the mean) were detected using one-way analysis of variance followed by post-test using Graphpad prism 7.0 for multiple comparisons.

Results EENNS $(400 \mathrm{mg} / \mathrm{kg})$ significantly improved the disease progression, body weight, and colon length of the animals as compared with the disease control group. Animal treated with EENNS $(400 \mathrm{mg} / \mathrm{kg}$ ) showed significantly improved colon mucosal damage index $(1.66 \pm 0.21)$ and DAI $(11.66 \pm 4.01)$ as compared with the disease control group. A higher level of SOD and catalase and a lower level of MDA were observed in animals treated with EENNS $(400 \mathrm{mg} / \mathrm{kg})$ as compared with the disease control group. Animals treated with EENNS $(400 \mathrm{mg} / \mathrm{kg}$ ) significantly decreased in NO and MPO levels as compared with the disease control group. A lower level of TNF- $\alpha$ $(561.94 \pm 14.84)$ was observed in EENNS $(400 \mathrm{mg} / \mathrm{kg})$-treated animals as compared with the disease control group ( $736.92 \pm 15.3)$. These observations were comparable to those of the standard control group. Histopathological data showed that EENNS $(400 \mathrm{mg} / \mathrm{kg})$ has shown reversal of tissue inflammation as compared with the disease published online March 7, 2022
DOI https://doi.org/ $10.1055 / \mathrm{s}-0042-1743133$. ISSN 0379-038X. (c) 2022. National Academy of Medical Sciences (India). All rights reserved.

This is an open access article published by Thieme under the terms of the Creative Commons Attribution-NonDerivative-NonCommercial-License, permitting copying and reproduction so long as the original work is given appropriate credit. Contents may not be used for commercial purposes, or adapted, remixed, transformed or built upon. (https://creativecommons.org/ licenses/by-nc-nd/4.0/)

Thieme Medical and Scientific Publishers Pvt. Ltd., A-12, 2nd Floor, Sector 2, Noida-201301 UP, India 
group and evidence of less cell infiltration of lymphocytes and monocytes with normal structures of goblet cell and crypts as compared with the disease group.

Conclusion EENS $(400 \mathrm{mg} / \mathrm{kg})$ can decrease the severity of the UC produced by DSS. EENNS showed a protective effect against DSS-induced ulcerative colitis which may be due to its antioxidant and anti-inflammatory activity.

\section{Introduction}

Inflammatory bowel disease (IBD) is characterized by an idiopathic chronic relapsing inflammatory condition and is classified into two major chronic conditions: (1) Crohn's disease (CD) and (2) ulcerative colitis (UC). ${ }^{1}$

UC involves recurrent uncontrolled inflammation of the colon and rectum in which the inflammation of rectum spreads from the distal colon to the proximal colon. ${ }^{2}$

The exact etiology of IBD remains unknown. It is mostly related to genetic and environmental factors. The pathophysiology of UC is incompletely understood, but some evidence suggests disturbance of the immune system or imbalanced interactions with microbes leading to development of chronic intestinal inflammation when certain environmental factors trigger genetically susceptible hosts. ${ }^{1}$

In India, the prevalence ratio of UC/CD is 8:1. ${ }^{3}$ Accordingly, several different animal models with defined knockouts of inflammatory factors such as interleukin (IL)-2, IL-10, and T cell receptor appear to result in bowel inflammation. ${ }^{4}$

Management of UC involves mainly use of immunosuppressive agents like steroids (corticosteroids), anti-inflammatory agents such as aminosalicylates, and antibiotics (e.g., metronidazole, ciprofloxacin). ${ }^{2}$

There is a need for an alternative agent compared with synthetic drugs for the management of the disease. ${ }^{2}$

Nelumbo nucifera, belonging to the family Nymphaeaceae, is one of the important traditional herbs. The seeds or their extracts have been reported to possess antiproliferative, antifibrosis, antidepressant, astringent, hepatoprotective and free-radical scavenging, antiobesity, hypolipidemic, anti-inflammatory, and antiviral activities. ${ }^{5}$ Seeds are used in folk medicines as treatment of tissue inflammation, cancer, skin disease, and leprosy. ${ }^{6}$

Neferine and isoliensinine, the major alkaloids of $N$. nucifera seeds, have been reported as inhibitors of tumor necrosis factor- $\alpha$ (TNF- $\alpha$ ) and NF-Kb (nuclear factor kappa b). ${ }^{7,8}$ Furthermore, rutin, the major flavonoid present in seeds, has antiulcer effect in dextran sulfate sodium (DSS)induced UC. ${ }^{9}$ So, this study was undertaken to evaluate the effect of $N$. nucifera seed extract in chemical-induced UC in rats.

\section{Materials and Methods}

\section{Plant Collection and Preparation of Extract}

Nelumbo nucifera seeds were collected from the Bhavnagar region and authentication was done at RK University, Rajkot (Authentication No. BKMGPC/919). Dried powder of seeds
$(100 \mathrm{~g})$ was macerated with $75 \%$ ethanol $(1,000 \mathrm{~mL})$ for 14 days and the extract was filtered through a filter paper and dried at room temperature. ${ }^{10}$

\section{Phytochemical Screening}

Phytochemical screening tests were performed in the ethanolic extract of $N$. nucifera seed (EENNS) for the presence of phytoconstituents. ${ }^{11}$

\section{LC-MS Analysis}

Liquid chromatography-mass spectrometry (LC-MS) analysis of EENNS was done for the estimation of presence of alkaloids (neferine and isoliensinine) and flavonoids (rutin) as per the specifications mentioned in - Table 1. ${ }^{12,13}$

\section{Experimental Animals}

Albino Wistar rats (250-300 g) of either sex were used and housed at temperature $25 \pm 1^{\circ} \mathrm{C}$, relative humidity 30 to $70 \%$, and $12 \mathrm{~h} / 12 \mathrm{~h}$ light dark cycle, and pelleted diet and purified drinking water were provided. The present study was conducted according to Institutional Animal Ethical Committee as per the guidance of the Committee for the Purpose of Control and Supervision of Experiments on Animals. The protocol approval number is BKMGPC/IAEC22/RP47/2018.

\section{Dextran Sulfate Sodium-Induced Ulcerative Colitis}

DSS (2\%) was given orally to all rats except the normal control group at 5 th to 11 th day to induce UC. On the 11th day, the animals were sacrificed and colonic parts were taken for macroscopic and other parameter examinations. ${ }^{14}$

\section{Study Design}

Animals were divided in six groups ( $n=6$ ), group I (normal control): rats received only vehicle (saline, p.o. [per oral]) daily for 11 days. ${ }^{14}$ Group II (disease control): $2 \%$ DSS was given orally to all the rats from 5 th to 11 th day to induce colitis with normal saline as a treatment. ${ }^{14}$ Group III (standard control): sulfasalazine $(50 \mathrm{mg} / \mathrm{kg})$ was given daily as a treatment with $2 \%$ DSS (p.o.) from 5th to 11 th day. ${ }^{14}$ Group IV (EENNS $200 \mathrm{mg} / \mathrm{kg}$ ): $200 \mathrm{mg} / \mathrm{kg}$ EENNS was administered daily (p.o.) for 11 days $+2 \%$ DSS from 5 th to 11 th day. Group V(EENNS $400 \mathrm{mg} / \mathrm{kg}$ ): $400 \mathrm{mg} / \mathrm{kg}$ EENNS was administered daily for 11 days $+2 \%$ DSS from 5 th to 11 th day. Group VI (EENNS $600 \mathrm{mg} / \mathrm{kg}$ ): $600 \mathrm{mg} / \mathrm{kg}$ EENNS was administered daily for 11 days with $2 \%$ DSS from 5 th to 11 th day. On 11 th day, rats were sacrificed and parameters were evaluated.

A reported study of sulphasalazine and EENNS having anti-inflammatory activity suggested better potency at 50 
Table 1 Specifications for LC/MS

\begin{tabular}{|l|l|}
\hline Parameters & Used \\
\hline Column & $\begin{array}{l}\text { MonoChrom C18 } \\
(4.6 \mathrm{~mm} \times 200 \mathrm{~mm}, 10 \mu \mathrm{m})\end{array}$ \\
\hline Mobile phase & $\begin{array}{l}\text { Acetonitrile-water:triethylamine } \\
(16: 84)\end{array}$ \\
\hline Flow rate & $1.4 \mathrm{~mL} / \mathrm{min}$ \\
\hline Column oven temperature & $30 \pm 2^{\circ} \mathrm{C}$ \\
\hline Auto sampler temperature & $15 \pm 3^{\circ} \mathrm{C}$ \\
\hline Volume of injection & $10 \mu \mathrm{L}$ \\
\hline Detector & PDA and Mass detector \\
\hline Detection wavelength & $230 \mathrm{~nm}$ \\
\hline Run time & 20.0 minutes \\
\hline Ion source & Electrospray ionization \\
\hline Polarity & Positive and negative \\
\hline
\end{tabular}

Abbreviations: LC, liquid chromatography, MS, mass spectrometry; PDA, photodiode-array detection.

and $400 \mathrm{mg} / \mathrm{kg}$, respectively; sulphasalazine has also been reported for having protective anti-UC activity at $50 \mathrm{mg} / \mathrm{kg}$. For EENNS $400 \mathrm{mg} / \mathrm{kg}$ as a therapeutic dose, the minimal and maximal doses selected of the extract were 200 and $600 \mathrm{mg} / \mathrm{kg}$.

\section{Evaluation Parameters}

\section{Change in Body Weight}

Weights of animals were recorded every day. The \% change in body weight was considered by dissimilarity between initial and final body weights of animal. ${ }^{15}$

\section{Measurement of Food and Water Intake}

Food and water intake was measured daily in all groups.

\section{Measurement of Colon Length}

On 11th day all the animals were sacrificed. The colon was removed by dissection and length of colon was calculated by keeping the colon on a graph paper and by checking the length using centimeter as standard. A sensitive weighing balance was used for measurement of colon weight. ${ }^{16}$
Colon Mucosal Damage Index

Colon segment of approximately $10 \mathrm{~cm}$ was excised, rinsed using sa1ine, and opened into midline. Macroscopic scoring was done from the luminal side of the colon segment.

\section{Disease Activity Index}

Disease activity index was calculated as per score shown in - Table 2 . $^{16}$

\section{Determination of Myeloperoxidase Activity}

$100 \mathrm{mg}$ colon mucosal scrapings were homogenized with PPB containing hexadecyl ammonium bromide. ${ }^{17}$ Homogenate was frozen at $20,000 \times \mathrm{g}$ for 15 minutes and centrifuged to verify myeloperoxidase (MPO) activity. ${ }^{17}$ The level of MPO activity was measured spectrophotometrically: $0.1 \mathrm{~mL}$ supernatant was mixed with $2.9 \mathrm{~mL}$ of $50 \mathrm{mM}$ phosphate buffer, containing o-dianisidine dihydrochloride $(0.167 \%)$ and $0.0005 \%$ hydrogen peroxide. ${ }^{17}$ Change in absorbance was recorded at $460 \mathrm{~nm}$ for 1 minute at an interval of 15 seconds. MPO activity was measured using the following formula:

MPO $(\mathrm{U} / \mathrm{mg})=$ Absorbance per minute $\times 10 x$,

where $x=10 \times$ change in observation per minute

volume of supernatant taken in the final reaction.

\section{Determination of NO Estimation}

Colon samples were thawed in $0.3 \mathrm{~mL}$ phosphate-buffered saline (PBS, pH 7.2 at $4^{\circ} \mathrm{C}$ ). Then weighed, homogenized, and centrifuged at $12,000 \mathrm{rpm}$ for 10 minutes. ${ }^{17}$ Then $2 \mathrm{~mL}$ of sodium nitroprusside dissolved in $0.5 \mathrm{~mL}$ PBS pH 7.4 was mixed with $0.5 \mathrm{~mL}$ of sample solution incubated at $25^{\circ} \mathrm{C}$ for 150 minutes. ${ }^{17}$ To this $0.5 \mathrm{~mL}$ of Griess reagent was added and incubated at room temperature. ${ }^{17}$ Nitric oxide (NO) concentration was determined by absorbance at $540 \mathrm{~nm}$. Calculation was done using a standard curve of sodium nitrate. ${ }^{17}$

\section{Estimation of TNF- $\alpha$ Level}

Standard curves of all the standards and samples were obtained for each assay. ${ }^{18} 50 \mu \mathrm{L}$ was added to wells of standards and $40 \mu \mathrm{L}$ samples were added to the plate. ${ }^{18}$ Then $50 \mu \mathrm{L}$ diluted detection antibody solution was added. ${ }^{18}$ $0.34 \mu \mathrm{L}$ diluted steptavidin-HRP solution was added and incubated for 60 minutes at $37^{\circ} \mathrm{C} .{ }^{18}$ Then the plate was washed five times with wash buffer (1X). ${ }^{18} 50 \mu \mathrm{L} \mathrm{TMB}$ (3,3',5,5'-tetramethylbenzidine) substrate $\mathrm{A}$ was added to

Table 2 Calculation of disease activity index score (DAI)

\begin{tabular}{|l|l|l|l|}
\hline Score & Weight loss & Stool constituency & Bleeding \\
\hline 0 & Normal & Normal (well-formed pellets) & Not observed \\
\hline 1 & $1-5 \%$ & Normal & Not observed \\
\hline 2 & $6-10 \%$ & Loose (pasty stools that do not stick the anus) & Occult \\
\hline 3 & $11-15 \%$ & Loose (pasty stools that do not stick the anus) & Occult \\
\hline 4 & $>15 \%$ & Diarrhea (liquid stools that stick to the anus) & Gross bleeding \\
\hline
\end{tabular}


$50 \mu \mathrm{L}$ substrate B and incubated in the dark for 10 minutes. Positive wells turned blue in color. ${ }^{18}$ The reaction was stopped by adding stop solution to each well. ${ }^{18}$ Positive wells turned from yellow to blue. Absorbance was measured at $450 \mathrm{~nm}$ within 10 minutes of stopping reaction. ${ }^{18}$

\section{Antioxidant Studies}

\section{Measurement of Malondialdehyde Activity}

$1 \mathrm{~mL}$ of supernatant was mixed with $2 \mathrm{~mL}$ of $10 \%(\mathrm{w} / \mathrm{v})$ trichloroacetic acid stood in ice for approximately 15 minutes. ${ }^{17}$ The precipitates were separated by centrifugation. Then $2 \mathrm{~mL}$ sample of the clear supernatant solution was mixed with $2 \mathrm{~mL}$ aqueous $0.67 \%$ thiobarbituric acid and was heated in a boiling water bath for 10 minutes. ${ }^{17}$ The solution was cooled in ice for 5 minutes, and absorbance was measured at $535 \mathrm{~nm}$ against an appropriate blank solution. ${ }^{17}$ The level of malondialdehyde (MDA) was calculated by using a molar extinction coefficient of $1.49 \times 10^{5} \mathrm{~m}^{-1} \mathrm{~cm}^{-1}$. $^{17}$

\section{Determination of Superoxide Dismutase Activity}

$0.1 \mathrm{~mL}$ supernatant of the sample was mixed with $0.1 \mathrm{~mL}$ EDTA $\left(1 \times 10^{-4} \mathrm{M}\right), 0.5 \mathrm{~mL}$ of carbonate buffer $(\mathrm{pH} 9.7)$, and $1 \mathrm{~mL}$ of epinephrine $\left(3 \times 10^{-3} \mathrm{M}\right) \cdot{ }^{19}$ The optical density of the formed adrenochrome was measured at $480 \mathrm{~nm}$ for 3 minutes at an interval of 30 seconds. ${ }^{19}$ The enzyme activity was explained as the concentration required for the retardation of the chromogen production by $50 \%$ in 1 minute under the defined assay conditions. ${ }^{19}$

\section{Measurement of Catalase Activity}

Homogenate was diluted with phosphate buffer for 20 times. ${ }^{16}$ Absorbance of the sample containing $2.00 \mathrm{~mL}$ distilled homogenate and $1 \mathrm{~mL} \mathrm{H}_{2} \mathrm{O}_{2}$ at $25^{\circ} \mathrm{C}$ was measured against a blank containing phosphate buffer. ${ }^{16}$ The reaction was started by addition of $\mathrm{H}_{2} \mathrm{O}_{2}$ and the reading was measured for 3 minutes at 30 second interval. ${ }^{16}$ The difference in absorbance per unit time was expressed as the activity. ${ }^{16}$ One unit was defined as the amount of enzyme required to decompose $1.0 \mathrm{M}$ of $\mathrm{H}_{2} \mathrm{O}_{2}$ per minute at $\mathrm{pH} 7.0$ and $25^{\circ} \mathrm{C}$. All antioxidant results were expressed as $\mathrm{U} / \mathrm{mg}$ protein. ${ }^{16}$

\section{Measurement of Total Protein}

$1 \mathrm{~mL}$ homogenate was added to $4 \mathrm{~mL}$ biuret reagent and incubated for 20 minutes at room temperature. Absorbance was measured at $550 \mathrm{~nm}$ against a blank reagent. The amount of total protein was calculated using graph bovine serum albumin $\left(A_{550}=2.26 \times 10^{-4}(\mu \mathrm{g} / \mathrm{mL})^{-1} \mathrm{~cm}^{-1}\right)$.

\section{Histopathology}

In $10 \%$ natural buffer formalin the tissue sample from colon was fixed overnight and processed, sectioned ( $4 \mu \mathrm{m}$ thick), and stained with hematoxylin and eosin. ${ }^{18}$

\section{Statistical Analysis}

Data were expressed as mean \pm standard error of the mean.

Significant differences were detected using one-way analysis of variance (ANOVA) followed by Tukey's test using Graphpad prism 7.0 for multiple comparisons. $p<0.05$ was considered statistically significant.

\section{Results}

\section{Plant Extraction}

The extraction of dry powdered of whole plant of $N$. nucifera seed was performed and \% yield was found to be $14 \% \mathrm{w} / \mathrm{w}$.

\section{Phytochemical Screening}

Phytochemical screening tests of EENNS showed presence of alkaloids, tannins, phenols, flavonoids, triterpenoids, steroids, carbohydrates, amino acids, and proteins.

\section{LC-MS Analysis of Ethanolic Extracts of $\boldsymbol{N}$. nucifera Seeds}

EENNS was analyzed by using LC-MS for the presence of neferine, isoliensinine, and rutin. Mass data for chemical constituents present in EENNS were as follows:

PDA (photodiode-array detection) chromatograms of neferine (12.80), isoliensinine (14.45), and rutin (14.45) present in EENNS are shown in - Fig. $\mathbf{1}$.

MS chromatograms of neferine (29.84), isoliensinine (12.74), and rutin (14.35) as chemical constituents of EENNS are shown in -Fig. 2.

\section{Effect of Ethanolic Extract of $\boldsymbol{N}$. nucifera Seeds on Body weight, Food Intake, and Water Intake of Rats}

There was significant reduction in body weight, food intake, and water intake during 5th to 11th day of DSS administration in the disease control group as compared with the normal control group $(55.00 \pm 4.28,13.60 \pm 4.66$, $0.85 \pm 0.005)$. Animals treated with standard drug sulfasalazine $(50 \mathrm{mg} / \mathrm{kg})$ showed significant reduction in body weight, food intake, and water intake as compared with the disease control group. Animals treated with EENNS $(400 \mathrm{mg} / \mathrm{kg}$ ) showed significant reduction in body weight, food intake, and water intake as compared with the disease control group $(11.66 \pm 4.01, \quad 19.84 \pm 0.81, \quad 0.12 \pm 0.015), \quad$ as shown in - Table 3.

\section{Effect of Ethanolic Extract of $\boldsymbol{N}$. nucifera Seeds on DAI Score}

The body weight was recorded every day in between $10.00 \mathrm{a}$. $\mathrm{m}$. and $11.00 \mathrm{a}$ a.m. from 5 th to 11 th day. Stool constituency and rectal bleeding were monitored daily in between $11.00 \mathrm{a}$. $\mathrm{m}$. and 12 p.m. At the end of 5th to 11th days of DSS administration $(2 \% \mathrm{w} / \mathrm{v})$, there was a significant increase in disease activity index (DAI) of the disease control group as shown in - Table 4.

Animals treated with standard drug sulfasalazine (50 $\mathrm{mg} / \mathrm{kg}$ ) showed significantly decrease DAI as compared with the disease control group. Animals treated with EENNS $(400 \mathrm{mg} / \mathrm{kg})$ showed significantly decreased DAI as compared with the disease control group as shown in -Table 4. 


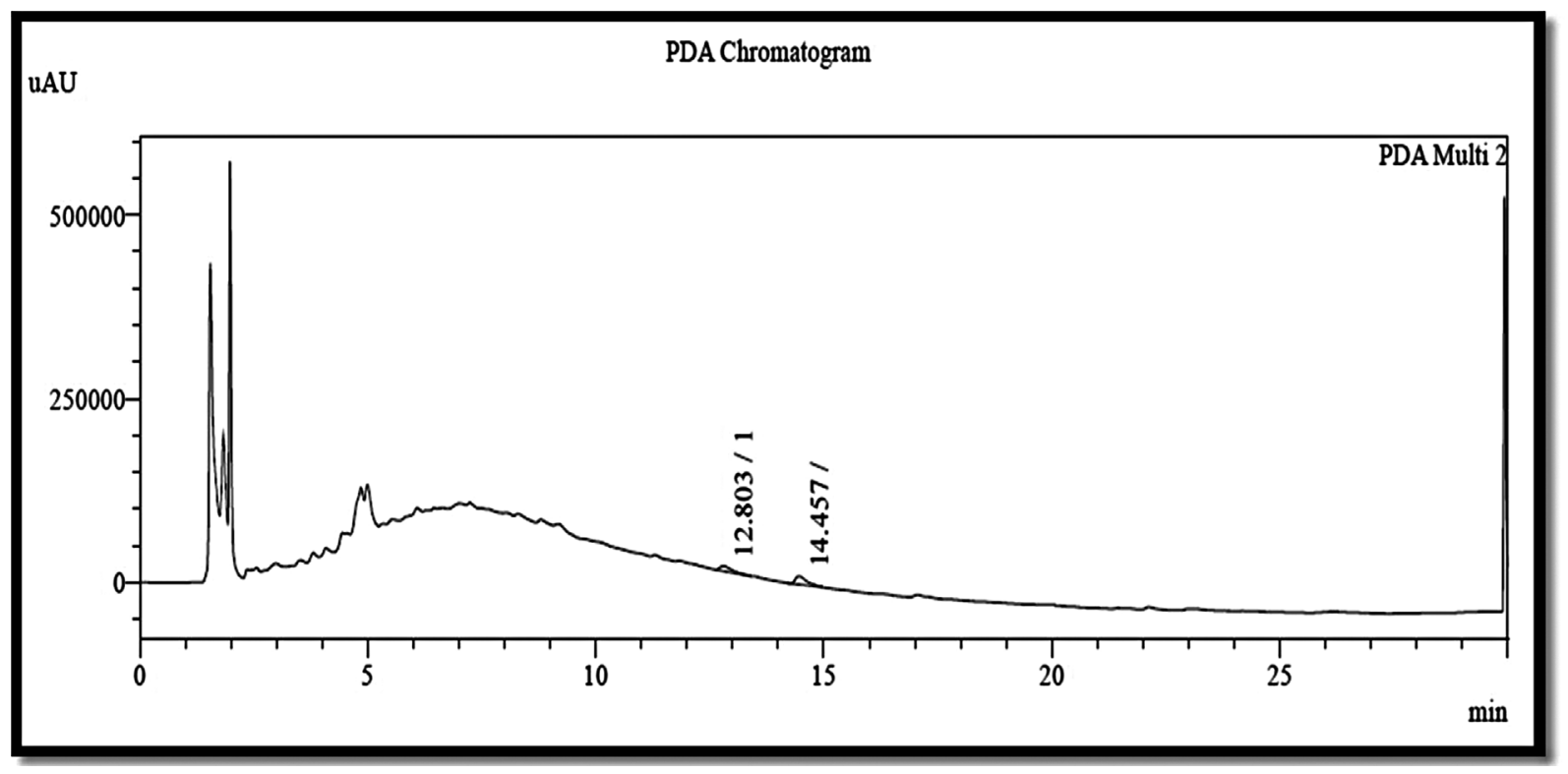

Fig. 1 PDA chromatogram of ethanolic extract of Nelumbo nucifera seed. PDA, photodiode-array detection.

From bleeding, loosed stool, and loss of body weight, DAI was calculated, and significant changes in DAI were found from day 7 to 11 as shown in - Fig. 3 .

\section{Effect of Ethanolic Extract of $\boldsymbol{N}$. nucifera Seeds on Colon Length}

Animals treated with standard drug sulfasalazine $(50 \mathrm{mg} / \mathrm{kg})$ showed significantly higher colon length $(12.90 \pm 0.10)$ as compared with the disease control group. Animals treated with EENNS $(400 \mathrm{mg} / \mathrm{kg})$ showed significantly higher colon length ( $12.60 \pm 0.12)$ as compared with the disease control group, as shown in - Table 3 and -Fig. 4.
Shortened length of colon and increased inflammation were observed in the disease control group, while the EENNS $(400 \mathrm{mg} / \mathrm{kg})$-pretreated group showed a protective effect on colon length and inflammation.

\section{Effect of Ethanolic Extract of $\boldsymbol{N}$. nucifera Seeds on Colon Mucosal Damage Index}

There was a significantly higher colon mucosal damage index (CMDI) score in the disease control group $(3.66 \pm 0.21)$ as compared with the normal control group $(0.00 \pm 0.00)$. Animals treated with standard drug sulfasalazine $(50 \mathrm{mg} / \mathrm{kg})$ showed a significantly lower CMDI $(1.16 \pm 0.16)$ as compared

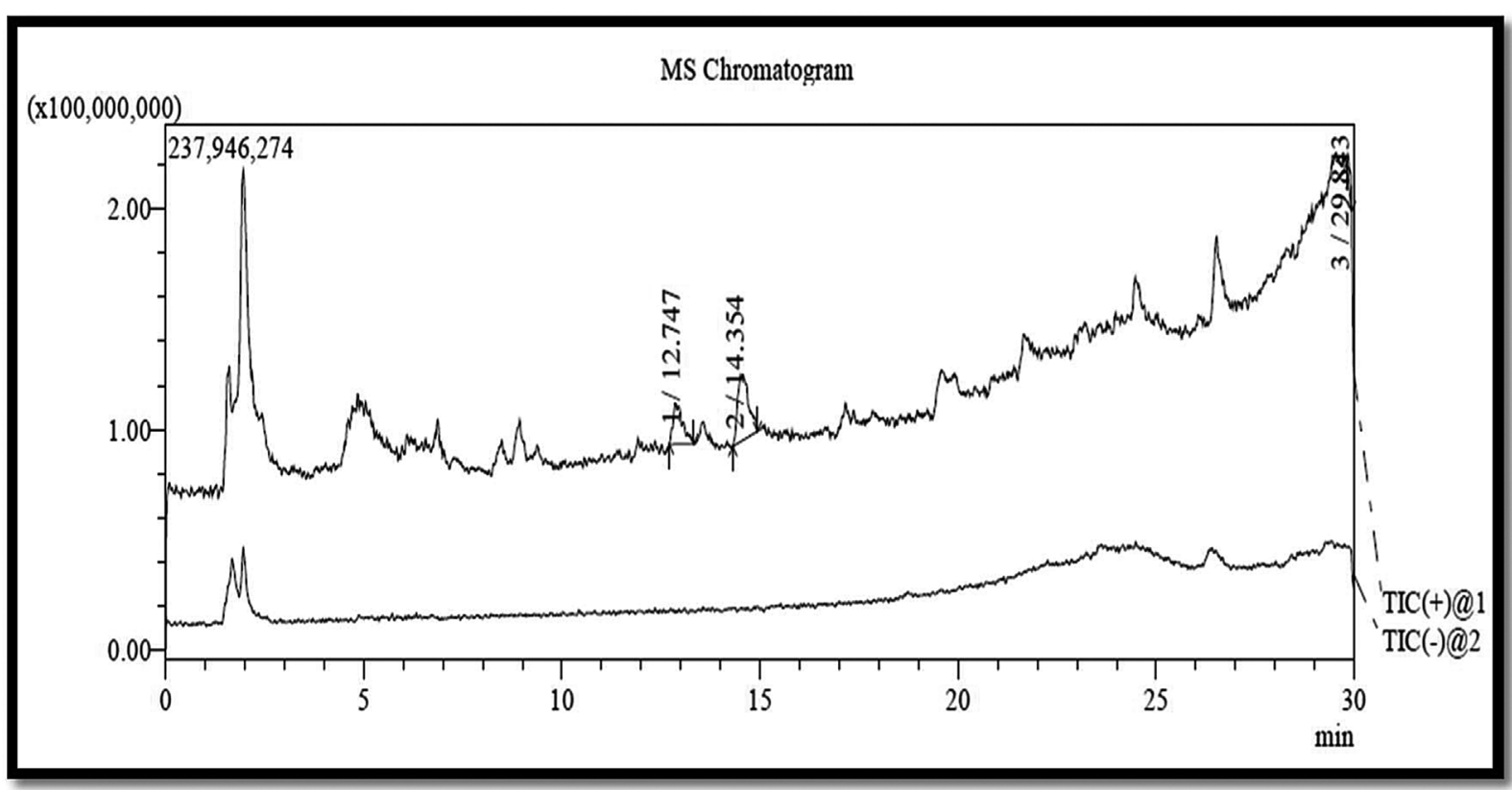

Fig. 2 MS chromatogram of ethanolic extract of Nelumbo nucifera seed. MS, mass spectrometry. 
Table 3 Effect of ethanolic extract of Nelumbo nucifera seeds (EENNS) on body weight, food intake, water intake, and colon length of rats in DSS-induced ulcerative colitis

\begin{tabular}{|l|l|l|l|l|}
\hline Groups & $\begin{array}{l}\text { Reduction in } \\
\text { body weight }(\mathbf{g})\end{array}$ & $\begin{array}{l}\text { \% inhibition in } \\
\text { food intake }(\mathbf{g})\end{array}$ & $\begin{array}{l}\text { \% difference in } \\
\text { water intake }(\mathrm{mL})\end{array}$ & Colon length (cm) \\
\hline Normal control & $0.00 \pm 0.00$ & $0.00 \pm 0.00$ & $0.00 \pm 0.00$ & $13.71 \pm 0.17$ \\
\hline Disease control & $55.00 \pm 4.28^{\mathrm{a}}$ & $13.60 \pm 4.66^{\mathrm{a}}$ & $0.85 \pm 0.005^{\mathrm{a}}$ & $10.10 \pm 0.25^{\mathrm{a}}$ \\
\hline Std. treatment (sulphasalazine) & $10.00 \pm 2.58^{\mathrm{b}}$ & $43.07 \pm 3.39^{\mathrm{b}}$ & $0.27 \pm 0.025^{\mathrm{b}}$ & $12.90 \pm 0.10^{\mathrm{b}}$ \\
\hline EENNS treatment $(200 \mathrm{mg} / \mathrm{kg})$ & $36.66 \pm 8.81$ & $19.20 \pm 2.51$ & $0.23 \pm 0.020^{\mathrm{b}}$ & $10.90 \pm 0.27$ \\
\hline EENNS treatment $(400 \mathrm{mg} / \mathrm{kg})$ & $11.66 \pm 4.01^{\mathrm{b}}$ & $19.84 \pm 0.81^{\mathrm{b}}$ & $0.12 \pm 0.015^{\mathrm{b}}$ & $12.60 \pm 0.12^{\mathrm{b}}$ \\
\hline EENNS treatment $(600 \mathrm{mg} / \mathrm{kg})$ & $8.33 \pm 8.72^{\mathrm{b}}$ & $40.21 \pm 0.64^{\mathrm{b}}$ & $0.13 \pm 0.020^{\mathrm{b}}$ & $12.73 \pm 0.11^{\mathrm{b}}$ \\
\hline
\end{tabular}

Note: All the values are expressed in mean \pm standard error of the mean $(n=6)$.

${ }^{a}$ Significantly different from normal control $(p<0.05)$.

bSignificantly different from disease control $(p<0.05)$.

Table 4 Effect on disease activity index after introduction of DSS in rats

\begin{tabular}{|l|l|l|l|l|l|l|}
\hline \multirow{2}{*}{ Day } & \multicolumn{3}{|l|}{ Group } & \multicolumn{3}{|l|}{} \\
\cline { 2 - 7 } & $\begin{array}{l}\text { Normal } \\
\text { control }\end{array}$ & $\begin{array}{l}\text { Disease } \\
\text { control }\end{array}$ & Standard $(50 \mathrm{mg} / \mathrm{kg})$ & EENNS (200 $\mathbf{m g} / \mathbf{k g})$ & EENNS (400 mg/kg) & EENNS (600 mg/kg) \\
\hline 7 & $0 \pm 0$ & $12.50 \pm 2.99^{\mathrm{a}}$ & $0.00 \pm 2.52^{\mathrm{b}}$ & $8.83 \pm 7.20$ & $1.66 \pm 1.66^{\mathrm{b}}$ & $3.33 \pm 5.57^{\mathrm{b}}$ \\
\hline 8 & $0 \pm 0$ & $13.33 \pm 4.73$ & $2.00 \pm 4.89$ & $11.33 \pm 5.43$ & $2.50 \pm 1.91$ & $5.33 \pm 4.93$ \\
\hline 9 & $0 \pm 0$ & $27.00 \pm 4.28$ & $5.00 \pm 3.41$ & $22.33 \pm 5.14$ & $5.33 \pm 3.33$ & $7.00 \pm 4.86$ \\
\hline 10 & $0 \pm 0$ & $42.00 \pm 4.47$ & $8.66 \pm 3.00$ & $32.50 \pm 8.18$ & $7.16 \pm 3.35$ & $8.33 \pm 6.54$ \\
\hline 11 & $0 \pm 0$ & $57.00 \pm 4.28$ & $10.00 \pm 2.52$ & $40.66 \pm 8.41$ & $11.66 \pm 4.01$ & $11.66 \pm 7.92$ \\
\hline
\end{tabular}

Abbreviations: DSS, dextran sodium sulfate; EENNS, ethanolic extract of Nelumbo nucifera seed.

Note: All the values are expressed in mean \pm standard error of the mean $(n=6)$.

a Significantly different from normal control $(p<0.05)$.

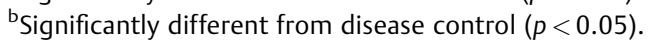

with the disease control group. Animals treated with EENNS $(400 \mathrm{mg} / \mathrm{kg})$ showed significantly lower CMDI $(1.66 \pm 0.21)$ as compared with the disease control group, as shown in - Table 5.

Edema was observed in DSS-treated experimental animals. ${ }^{20}$ EENNS (400 mg/kg) showed significant protection from macroscopic damage of colon as per the CMDI score, as shown in - Table 5 .

\section{Effect of Ethanolic Extract of $\boldsymbol{N}$. nucifera Seeds on MPO Activity}

There was a significant increase in MPO level in the disease control group $(3.33 \pm 0.19)$ as compared with the normal

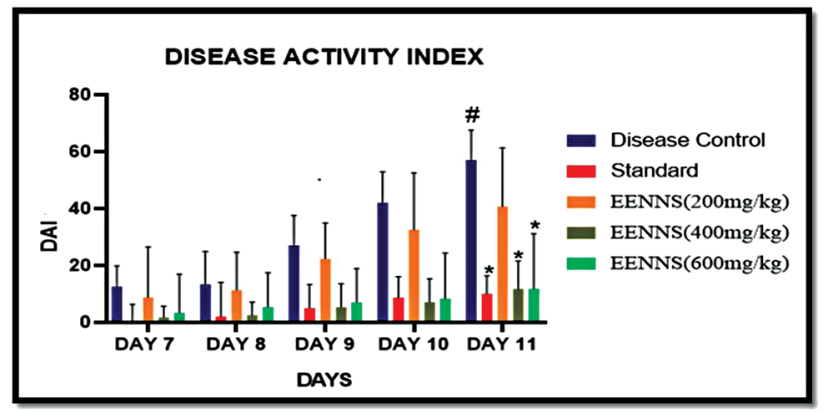

Fig. 3 Effect on disease activity index after introduction of DSS in rats. DSS, dextran sodium sulfate. control group $(1.91 \pm 0.15)$. Animals treated with standard drug sulfasalazine $(50 \mathrm{mg} / \mathrm{kg}$ ) showed a significant decrease in MPO level $(1.39 \pm 0.13)$ as compared with the disease control group. Animals treated with EENNS $(400 \mathrm{mg} / \mathrm{kg})$ showed a

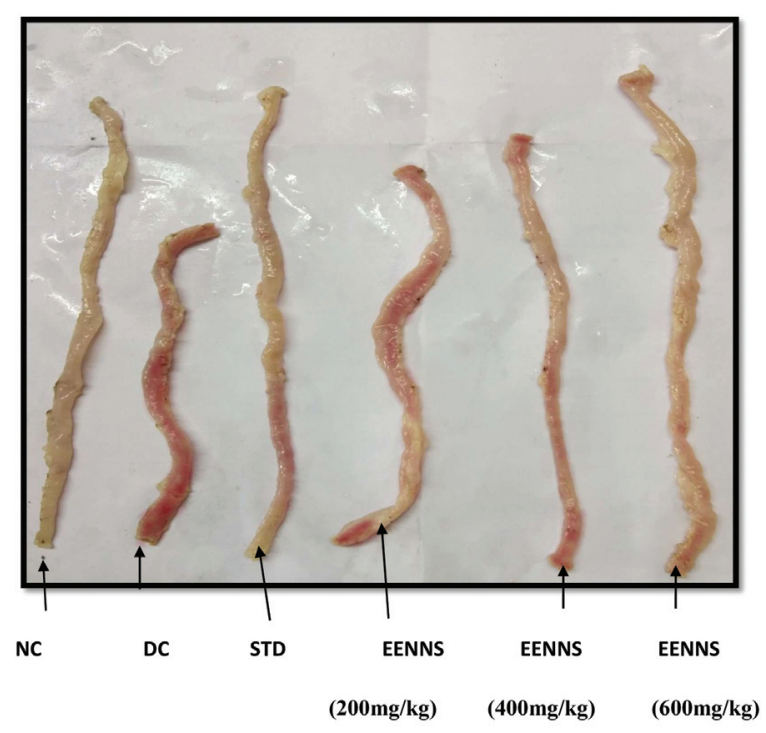

Fig. 4 Measurement of colon length. 
Table 5 Effect of ethanolic extract of Nelumbo nucifera seeds on CMDI score in DSS-induced ulcerative colitis

\begin{tabular}{|l|l|}
\hline Groups & CMDI score \\
\hline Normal control & $0.00 \pm 0.00$ \\
\hline Disease control & $3.66 \pm 0.21^{\mathrm{a}}$ \\
\hline Std. treatment (sulphasalazine) & $1.16 \pm 0.16^{\mathrm{b}}$ \\
\hline EENNS treatment $(200 \mathrm{mg} / \mathrm{kg})$ & $2.83 \pm 0.30$ \\
\hline EENNS treatment $(400 \mathrm{mg} / \mathrm{kg})$ & $1.66 \pm 0.21^{\mathrm{b}}$ \\
\hline EENNS treatment $(600 \mathrm{mg} / \mathrm{kg})$ & $1.33 \pm 0.21^{\mathrm{b}}$ \\
\hline
\end{tabular}

Abbreviations: CMDI, colon mucosal damage index; DSS, dextran sodium sulfate.

Note: All the values are expressed in mean \pm standard error of the mean $(n=6)$.

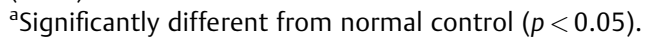

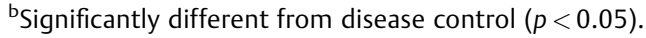

significant decrease in MPO level $(1.60 \pm 0.19)$ as compared with the disease control group, as shown in - Table 6 .

\section{Effect of Ethanolic Extract of $\boldsymbol{N}$. nucifera Seeds on NO Activity}

There was a significant increase in NO level in the disease control group $(0.25 \pm 0.014)$ as compared with the normal control group $(0.17 \pm 0.009)$. Animals treated with standard drug sulfasalazine $(50 \mathrm{mg} / \mathrm{kg})$ showed a significant decrease in NO level $(0.15 \pm 0.006)$ as compared with the disease control group. Animals treated with EENNS $(400 \mathrm{mg} / \mathrm{kg}$ ) showed a significant decrease in NO level $(0.19 \pm 0.008)$ as compared with the disease control group, as shown in -Table 6.

\section{Effect of Ethanolic Extract of $\boldsymbol{N}$. nucifera Seeds on TNF- $\alpha$ Level}

There was a significant increase in TNF- $\alpha$ level in the disease control group (736.92 \pm 15.3$)$ as compared with the normal control group $(458.02 \pm 6.36)$. Animals treated with standard drug sulfasalazine $(50 \mathrm{mg} / \mathrm{kg}$ ) showed a significant decrease in TNF- $\alpha$ level ( $520.70 \pm 30.96)$ as compared with the disease control group. Animals treated with EENNS $(400 \mathrm{mg} / \mathrm{kg}$ ) showed a significant decrease in TNF- $\alpha$ level $(841.60 \pm 0.19)$ as compared with the disease control group.

\section{Effect of Ethanolic Extract of $\boldsymbol{N}$. nucifera Seeds on MDA Level}

There was a significant increase in MDA level in the disease control group $(0.41 \pm 0.003)$ as compared with the normal control group $(0.19 \pm 0.053)$. Animals treated with standard drug sulfasalazine $(50 \mathrm{mg} / \mathrm{kg}$ ) showed a significant decrease in MDA level $(0.16 \pm 0.034)$ as compared with the disease control group. Animals treated with EENNS (400 mg/kg) showed a significant decrease in MDA level $(0.14 \pm 0.025)$ as compared with the disease control group, as shown in - Table 6 .

\section{Effect of Ethanolic Extract of $N$. nucifera Seeds on SOD Level}

There was a significant decrease in superoxide dismutase (SOD) level in the disease control group $(3.09 \pm 0.33)$ as compared with the normal control group $(29.40 \pm 0.80)$. Animals treated with standard drug sulfasalazine $(50 \mathrm{mg} / \mathrm{kg})$ showed a significant increase in SOD level $(26.97 \pm 2.16)$ as compared with the disease control group. Animals treated with EENNS $(400 \mathrm{mg} / \mathrm{kg}$ ) showed a significant increase in SOD level $(15.39 \pm 2.09)$ as compared with the disease control group as shown in - Table 6 .

EENNS (400 mg/kg) significantly increased SOD level as compared with the disease group.

\section{Effect of Ethanolic Extract of $\boldsymbol{N}$. nucifera Seeds on Catalase Level}

There was significant decrease in catalase (CT) level in the disease control group $(0.54 \pm 0.16)$ as compared with the normal control group $(2.75 \pm 0.50)$. Animals treated with

Table 6 Effect of ethanolic extract of Nelumbo nucifera seeds on MPO, NO, TNF- $\alpha$, MDA, SOD, and CT level in DSS-induced ulcerative colitis in rats

\begin{tabular}{|l|l|l|l|l|l|l|}
\hline Groups & $\begin{array}{l}\text { MPO }(\mathrm{U} / \mathrm{mg} \\
\text { of protein) }\end{array}$ & $\begin{array}{l}\text { NO }(\mu \mathrm{mol} / \mathrm{mg} \\
\text { of protein) }\end{array}$ & TNF- $\alpha(\mathrm{pg} / \mathrm{mL})$ & $\begin{array}{l}\text { MDA ( } \mu \mathrm{mol} / \mathrm{mg} \\
\text { of protein) }\end{array}$ & $\begin{array}{l}\text { SOD (U/mg } \\
\text { of protein) }\end{array}$ & $\begin{array}{l}\text { CT }(\mathrm{U} / \mathrm{mg} \\
\text { of protein) }\end{array}$ \\
\hline Normal & $1.91 \pm 0.15$ & $0.17 \pm 0.009$ & $458.02 \pm 6.36$ & $0.19 \pm 0.053$ & $29.40 \pm 0.80$ & $2.75 \pm 0.50$ \\
\hline Disease & $3.33 \pm 0.19^{\mathrm{a}}$ & $0.25 \pm 0.014^{\mathrm{a}}$ & $736.92 \pm 15.3^{\mathrm{a}}$ & $0.41 \pm 0.003^{\mathrm{a}}$ & $3.09 \pm 0.33^{\mathrm{a}}$ & $0.54 \pm 0.16^{\mathrm{a}}$ \\
\hline Std. (sulphasalazine) & $1.39 \pm 0.13^{\mathrm{b}}$ & $0.15 \pm 0.006^{\mathrm{b}}$ & $520.70 \pm 30.96^{\mathrm{b}}$ & $0.16 \pm 0.034^{\mathrm{b}}$ & $26.97 \pm 2.16^{\mathrm{b}}$ & $2.32 \pm 0.29^{\mathrm{b}}$ \\
\hline $\begin{array}{l}\text { EENNS }(200 \mathrm{mg} / \mathrm{kg}) \\
\text { treatment }\end{array}$ & $2.57 \pm 0.13^{\mathrm{b}}$ & $0.23 \pm 0.010$ & $667.23 \pm 22.47$ & $0.34 \pm 0.049$ & $5.98 \pm 0.77$ & $063 \pm 0.14$ \\
\hline $\begin{array}{l}\text { EENNS }(400 \mathrm{mg} / \mathrm{kg}) \\
\text { treatment }\end{array}$ & $1.60 \pm 0.19^{\mathrm{b}}$ & $0.19 \pm 0.008^{\mathrm{b}}$ & $561.94 \pm 14.84^{\mathrm{b}}$ & $0.14 \pm 0.025^{\mathrm{b}}$ & $15.39 \pm 2.09^{\mathrm{b}}$ & $1.60 \pm 0.31$ \\
\hline $\begin{array}{l}\text { EENNS }(600 \mathrm{mg} / \mathrm{kg}) \\
\text { treatment }\end{array}$ & $1.49 \pm 0.20^{\mathrm{b}}$ & $0.18 \pm 0.005^{\mathrm{b}}$ & $468.24 \pm 11.82^{\mathrm{b}}$ & $0.18 \pm 0.0017^{\mathrm{b}}$ & $25.18 \pm 1.67^{\mathrm{b}}$ & $2.40 \pm 0.35^{\mathrm{b}}$ \\
\hline
\end{tabular}

Abbreviations: $\mathrm{CT}$, catalase; DSS, dextran sodium sulfate; MDA, malondialdehyde; MPO, myeloperoxide; NO, nitric oxide; SOD, superoxide dismutase; TNF- $\alpha$, tumor necrosis factor $\alpha$.

Note: All the values are expressed in mean \pm standard error of the mean $(n=6)$.

aSignificantly different from normal control $(p<0.05)$.

bSignificantly different from disease control $(p<0.05)$. 
standard drug sulfasalazine $(50 \mathrm{mg} / \mathrm{kg}$ ) showed a significant increase in CT level $(2.32 \pm 0.29)$ as compared with the disease control group. Animals treated with EENNS (600 $\mathrm{mg} / \mathrm{kg})$ showed a significant increase in CT level $(2.40 \pm 0.35)$ as compared with the disease control group as shown in - Table 6.

EENNS showed a significant increase in CT level as compared with the disease control group.

\section{Histopathology}

All typical changes were observed in the DSS-receiving group as shown in - Fig. 5 (panel 2). The standard control group showed a decrease in influx of neutrophils into the lamina propria and submucosa. The goblet cell and crypt structure were found to be normal as compared with the disease control group, as shown in - Fig. 5 (panel 3).

The pretreated group with EENNS $(200 \mathrm{mg} / \mathrm{kg}$ ) showed dilation of intestinal gland and transmural inflammation and epithelial damage cell infiltration as shown in $\mathbf{- F i g . ~} \mathbf{5}$ (panel 4), while EENNSs (400 and $600 \mathrm{mg} / \mathrm{kg}$ ) were found normal goblet cell structure and normal mucosal structure with lesser cell infiltration as shown in -Fig. 5 (panels 5 and 6). This study showed a protective effect of EENNS against DSSinduced UC in rats.

\section{Discussion}

In UC, the intestinal lamina propria is associated with macrophage and lymphocyte mononuclear cell infiltration. Macrophages, a major population of tissue-resident mononuclear phagocytes, play a key role in recognition and elimination of bacteria. They produce proinflammatory cytokines in response to activated Th1 cells and induced tissue damage and hence causing bleeding, diarrhea, and loss of body weight. ${ }^{16}$

The process of digestion breaks food down using specialized proteins called enzymes. The small intestine contains intestinal glands called crypts of Lieberkuhn that secrete digestive enzyme. In disease condition small intestine cannot produce such kind of digestive enzymes. Hence food remains without breaking down, so the body does not need to consume food and thus a decrease in food intake in DSStreated animals. ${ }^{16}$

In normal body, absorbance of nutrients, salts, and water is necessary to provide energy. Due to the injury caused in the intestinal wall by DSS, it fails to absorb important salts and water thus water intake decreases in disease control animals. ${ }^{16}$

Macrophages, a major population of tissue-resident mononuclear phagocytes, play a key role in recognition and elimination of bacteria. They produce proinflammatory cytokines in response to activated Th1 cells and induced tissue damage and hence it causes bleeding, diarrhea, and loss of body weight. ${ }^{16}$ Characteristic colon length is a definite indicator of UC.

MPO activity helps in the assessment of polymorphonuclear (PMN) cell infiltration as a measure of inflammatory injury of colon. ${ }^{17}$ Migration and extravasations of circulatory
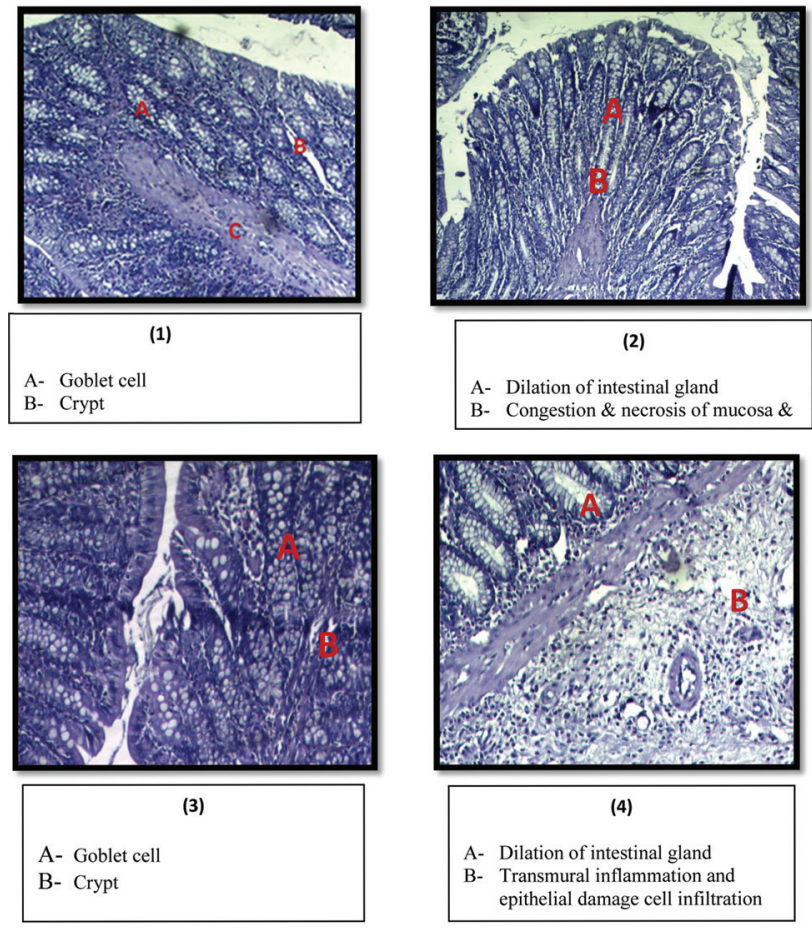

(4)

A- Dilation of intestinal gland

B- Transmural inflammation and epithelial damage cell infiltration

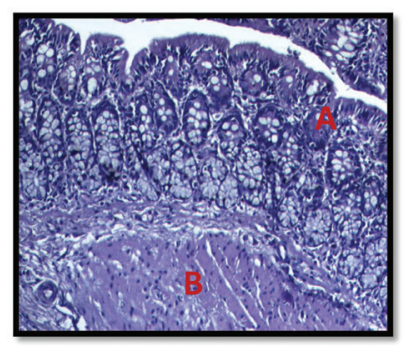

(5)
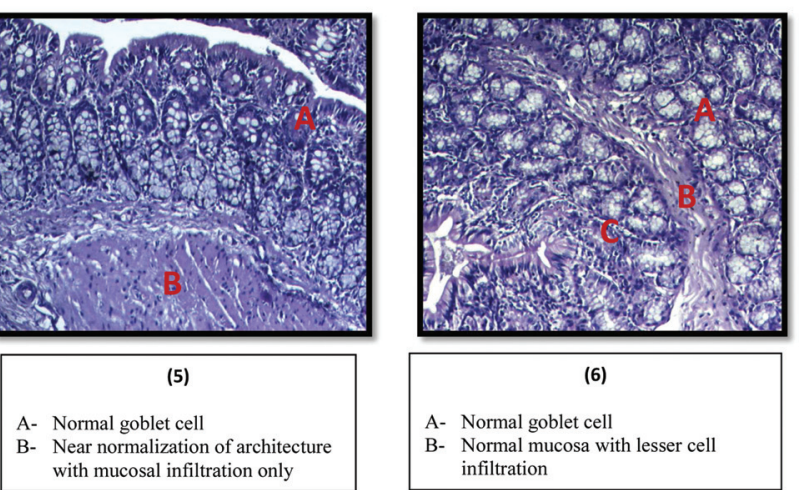

(6)

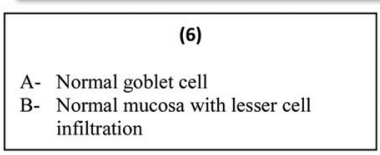

Fig. 5 Effect of ethanolic extract of Nelumbo nucifera seeds (EENNS) on histopathology of colon in DSS-induced ulcerative colitis. 1: normal control; 2: disease control (DSS 2\% w/v); 3: standard control (sulfasalazine $50 \mathrm{mg} / \mathrm{kg}$ ); 4: EENNS (200 mg/kg); 5: EENNS (400 mg/kg); 6 : EENNS $(600 \mathrm{mg} / \mathrm{kg})$. DSS, dextran sodium sulfate.

PMNs contribute markedly to chronic inflammatory injury of colon in UC. ${ }^{17}$

Inhibition of MPO activity in the pretreated group might be due to presence of phytoconstituents in N. nucifera seed such as neferine and isoliensinine. Cells synthesize NO by utilizing different isoforms of the enzyme NO synthase, which convert L-arginine to L-citrulline and NO. ${ }^{17}$ In the presence of oxygen, $\mathrm{NO}$ decomposes to nitrite $\left(\mathrm{NO}_{2}{ }^{-}\right)$and nitrate $\left(\mathrm{NO}_{3}{ }^{-}\right)$. NO released after cytokine stimulation is a potent agent in nonspecific defense mechanisms. ${ }^{17}$

DSS significantly causes an increase in production of all proinflammatory cytokines in both mid and distal colons; one of them (TNF- $\alpha$ ) is responsible for the inflammatory action by making tissue injury and infiltration of lymphocytes. Hyperemia of mesenteric arteries and fibrinous adhesion to other bowl tissues were observed. ${ }^{18}$ 
We noted a significant rise in the levels of MDA in colon homogenates of the DSS-treated group as compared with normal control groups. ${ }^{17}$ EENNS has antioxidant activity via scavenging property against DPPH, which is probably due to the presence of phytoconstituents like flavanoid. $^{20,21}$

As per the study it can be concluded that anti-UC activity of EENNS might be due to presence of phytoconstituents such as neferine, isoliensinine, and rutin. Furthermore, more studies of $N$. nucifera seed are required.

\section{Conclusion}

EENS ( $400 \mathrm{mg} / \mathrm{kg}$ ) can decrease the severity of the UC produced by DSS. Animals treated with EENNS $(400 \mathrm{mg} / \mathrm{kg}$ ) showed a significantly higher colon length. While, CMDI and DAI were significantly lower as compared with the disease control group. There was a significant increase in parameters related to oxidative stress like SOD and CT, and a significantly decrease in lipid peroxidation (MDA) and parameters related to inflammation such as NO, MPO, and TNF- $\alpha$ level in animals treated with EENNS ( $400 \mathrm{mg} / \mathrm{kg}$ ) as compared with the disease control group. Histopathologically, treatment groups showed reversal of tissue inflammation and evidence of less cell infiltration with normal structure of mucosa, goblet cell, and crypts. All these parameters might be responsible for the protective effect of EENNS. Further studies are suggested to isolate the active principle responsible for the activity and to confirm the exact mechanism of action.

\section{Conflict of Interest}

None declared.

\section{Acknowledgment}

The authors wish to thank the B. K. Mody Govt. Pharmacy College for providing laboratory facility for this research work.

\section{References}

$1 \mathrm{Kim} \mathrm{DH}$, Cheon JH. Pathogenesis of inflammatory bowel disease and recent advances in biologic therapies. Immune Netw 2017;17 (01):25-40

2 Su HJ, Chiu YT, Chiu CT, et al. Inflammatory bowel disease and its treatment in 2018: Global and Taiwanese status updates. J Formos Med Assoc 2019;118(07):1083-1092

3 Ray G. Inflammatory bowel disease in India - past, present and future. World J Gastroenterol 2016;22(36):8123-8136

4 Lee SH, Kwon JE, Cho ML. Immunological pathogenesis of inflammatory bowel disease. Intest Res 2018;16(01):26-42

5 Ke F, Yadav PK, Ju LZ. Herbal medicine in the treatment of ulcerative colitis. Saudi J Gastroenterol 2012;18(01):3-10
6 Bhardwaj A, Modi KP. A review on therapeutic potential of Nelumbo nucifera (Gaertn): the sacred lotus. Int J Pharm Sci Res 2016;7(01):42-54

7 Zhao L, Wang X, Chang Q, et al. Neferine, a bisbenzylisoquinline alkaloid attenuates bleomycin-induced pulmonary fibrosis. Eur J Pharmacol 2010;627(1-3):304-312

8 Xiao JH, Zhang JH, Chen HL, Feng XL, Wang JL. Inhibitory effects of isoliensinine on bleomycin-induced pulmonary fibrosis in mice. Planta Med 2005;71(03):225-230

9 Kwon KH, Murakami A, Tanaka T, Ohigashi H. Dietary rutin, but not its aglycone quercetin, ameliorates dextran sulfate sodiuminduced experimental colitis in mice: attenuation of pro-inflammatory gene expression. Biochem Pharmacol 2005;69(03): 395-406

10 Wethangkaboworn Y, Munglue P. Effect of ethanolic seed extract of Nelumbo nucifera on male rat sexual behavior. KKU Res J 2014;19(Supplement Issue):156-161

11 Kokate CK, Gokhle SB, Purohit AP. Pharmacognosy. Pune: Nirali Prakashan; 2009

12 Chen Y, Fan G, Wu H, Wu Y, Mitchell A. Separation, identification and rapid determination of liensine, isoliensinine and neferine from embryo of the seed of Nelumbo nucifera Gaertn. by liquid chromatography coupled to diode array detector and tandem mass spectrometry. J Pharm Biomed Anal 2007;43(01): 99-104

13 Paranthaman R, Praveen Kumar P, Kumaravel S. GC-MS analysis of phytochemicals and simultaneous determination of flavonoids in Amaranthus caudatus (Sirukeerai) by RP-HPLC. J Anal Bioanal Tech 2012;3(05):1-4

14 Vikrama Chakravarthi P, Gopakumar N, Nair AMC, Joy AD. Antiinflammatory activity of Red and White Lotus seeds (Nelumbo nucifera) in Albino Rats. Vet World 2010;3(04):157-159

15 Patel SH, Rachchh MA, Jadav PD. Evaluation of anti-inflammatory effect of anti-platelet agent-clopidogrel in experimentally induced inflammatory bowel disease. Indian J Pharmacol 2012;44 (06):744-748

16 Chaudhary G, Mahajan UB, Goyal SN, Ojha S, Patil CR, Subramanya SB. Protective effect of Lagerstroemia speciosa against dextran sulfate sodium induced ulcerative colitis in C57BL/6 mice. Am J Transl Res 2017;9(04):1792-1800

17 Koppikar SJ, Jagtap SD, Devarshi PP, et al. Triphala, an Ayurvedic formulation improves the antioxidant status on TNBS induced IBD in rats. Eur J Integr Med 2014;6(06):646-656

18 Camacho-Barquero L, Villegas I, Sánchez-Calvo JM, et al. Curcumin, a Curcuma longa constituent, acts on MAPK p38 pathway modulating COX-2 and iNOS expression in chronic experimental colitis. Int Immunopharmacol 2007;7(03): 333-342

19 Pandurangan AK, Mohebali N, Norhaizan ME, Looi CY. Gallic acid attenuates dextran sulfate sodium-induced experimental colitis in BALB/C mice. Drug Des Devel Ther 2015; 9:3923-3934

20 Lin JY, Lai YS, Liu CJ, Wu AR. Effects of lotus plumule supplementation before and following systemic administration of lipopolysaccharide on the splenocyte responses of BALB/c mice. Food Chem Toxicol 2007;45(03):486-493

21 Randhawa PK, Singh K, Singh N, Jaggi AS. A review on chemicalinduced inflammatory bowel disease models in rodents. Korean J Physiol Pharmacol 2014;18(04):279-288 